\title{
UNIVERSITYOF
}

FORWARD

THINKING

WESTMINSTER用

WestminsterResearch

http://www.westminster.ac.uk/westminsterresearch

Winston Churchill and the General Strike

Catterall, Peter

This is an Accepted Manuscript of a book chapter published by Bloomsbury Academic in Toye, R. (ed.) Winston Churchill: Politics, Strategy and Statecraft on 12th January 2017, available online:

http://www.bloomsbury.com/uk/winston-churchill-9781474263856/

The WestminsterResearch online digital archive at the University of Westminster aims to make the research output of the University available to a wider audience. Copyright and Moral Rights remain with the authors and/or copyright owners.

Whilst further distribution of specific materials from within this archive is forbidden, you may freely distribute the URL of WestminsterResearch: ((http://westminsterresearch.wmin.ac.uk/)).

In case of abuse or copyright appearing without permission e-mail repository@westminster.ac.uk 


\section{Churchill and the General Strike}

Dr Peter Catterall, University of Westminster

\section{Synopsis}

Churchill made clear his concerns about the constitutional challenge posed by a general strike long before the events of May 1926. However, his role in the run-up to those events was largely confined to agreeing the subsidy for the mining industry in July 1925 which postponed the conflagration. Churchill's profile, not least through involvement with the British Gazette, nevertheless led to some exaggeration of his part in events, though not of his hostility to a general strike. The coal dispute which helped to spark it, was however for him a very different matter, and Churchill tried hard if unsuccessfully to resolve this during the autumn of 1926.

\section{Essay}

'Business is all disorganised ... hideous reciprocal injuries are being inflicted by British hands on British throats', Winston Churchill lamented in the Commons on 31 August 1926. To reinforce the point, Parliament had just been recalled to renew the state of emergency deemed necessary by Stanley Baldwin’s Conservative government in face of bitter industrial conflict. The difficulty of resolving the prolonged coal dispute was clearly expressed by Churchill: the government was confronted by miners repeatedly demanding a subsidy, while 'all the owners say to us is, "Leave us alone”’. In seeking resolution Churchill acknowledged the widespread view that he was not the man for the job: 'One set of criticism is that the Prime Minister is always anxious to be very tender-hearted and make peaceful settlements, and that I am the marplot who frequently comes forward and intervenes to obstruct.' ${ }^{1}$ This view was particularly common among his political opponents. The parliamentary report to the 1926 Labour Party conference made clear Churchill's reputation in industrial disputes, noting with 
surprise of this debate: 'the Chancellor of the Exchequer [Churchill] made, for him, a very pacificatory speech, bringing with it a distinct improvement in the atmosphere'. ${ }^{2}$

The crisis originated in the industrial travails following the First World War. The much more heavily unionized labour force that emerged from the conflict responded to wartime inflation, taking advantage of a post-war boom to recover real wage levels. These shot up to around 30 per cent above pre-war norms, while hours were reduced. Interest rates were meanwhile increased both to choke off resultant inflationary pressures and to help restore sterling to prewar levels, while government spending was drastically cut from 1921. The result was reduced productivity and profitability and a credit squeeze just as the short boom ended in 1920-21. All this restricted investment and exacerbated the problems of staple industries now hit hard by a combination of the over-capacity encouraged during the war and the wartime loss of export markets. In response, businesses tried to reduce their costs, not least by reducing wages, a process resisted with varying success by the trade unions.

Probably the most politically sensitive sector affected by these developments was the coalmining industry, which was vital for domestic heating, transport, and electricity and gas generation. A very fragmented industry of some 1,400 firms employed over a million men in dirty and dangerous work. Wartime necessity led to it being put under state control in 1916, with additional pits that later proved uneconomic brought into operation. ${ }^{3}$ Making permanent this situation and rationalizing the industry through nationalization was narrowly recommended by a Royal Commission report to David Lloyd George’s coalition government in 1919. Churchill, who was then Secretary of State for War and Air, shared the Cabinet view instead favouring regulation, though labour underground was reduced by the Seven Hours Act 1919. Subsequently, with the post-war boom receding and prices and profits falling, the 
coalition instead decided to decontrol the industry in March 1921.

There followed a dress rehearsal for 1926. Mine-owners of what were now often unprofitable pits blamed the government for their plight, especially in the once-thriving export districts, hit by wartime import-substitution and replacement by reparations coal from Germany. They saw no solution other than to cut costs by reducing wages. The Miners’ Federation of Great Britain (MFGB) resisted these moves and the government invoked the Emergency Powers Act 1920 (EPA) to declare a state of emergency. However, on the pretext that the MFGB had turned down opportunities for settlement, the railwaymen and transport workers did not support them, calling off their planned sympathy action on 15 April 1921.

The spectre of a national dispute, led by the ‘Triple Alliance' of coal, rail and transport workers that could halt the economy, first emerged in 1914. Three years earlier Churchill had already drafted a lengthy note reflecting on the rising problem of politically motivated strikes. 'Thirty years ago the "general strike” was a very shadowy proposal', the then Home Secretary observed; 'now it is a definite objective deliberately advocated. ${ }^{4}$ Churchill regarded a General Strike as a deliberate political project, later arguing that after 1919, through 'a group of extremists in the Trade Union movement ... a whole literature upon a General Strike as the supreme weapon of labour came into existence’. Although Churchill always expected the majority of trade unionists to stand by parliamentary rule, the risk that a General Strike could be used to make government 'surrender to force what they would not concede to parley', ${ }^{5}$ not least by denying food supplies, led him in 1919 to advocate the deployment of troops 'if it was a question of saving lives' ${ }^{6}$ Anxieties about industrial conflict that year also led to the creation of the Cabinet's Supply and Transport Committee (STC). 
The new Baldwin Cabinet which Churchill joined in November 1924 immediately decided to continue with 'The Supply and Transport Organisation [STO], which former Governments have relied on in times of industrial crisis for the maintenance of supplies essential to the life of the civil community'. This provided a nucleus organization to apply a code of emergency regulations drafted under the EPA. A statement that 'The Mines Department consider that this selected code contains all the powers which they would require at the outset of the emergency’ made clear where such a crisis was expected to occur. ${ }^{7}$

When these words were written in July 1925, problems had returned in the coal industry. Temporarily the Franco-Belgian occupation of the German coalfields in January 1923 brought prosperity to the British industry, during which an increased minimum wage was agreed under the 1924 Labour government. The occupation, however, was ended by the Dawes Plan in September 1924. This prompted falling export prices for British coal, increasing pressure to reduce labour costs. Then, on 28 April 1925, Churchill announced a return to the Gold Standard. ${ }^{8}$ Churchill had justified the policy on grounds of international price stability but, as the economist John Maynard Keynes warned, because he did so at the pre-war parity with the dollar, prices would have to fall in Britain in order to adjust to a now over-valued currency. If, Keynes argued, prices and wages could fall across the entire economy by 10 per cent, then this might have minimal effects on real wages. The likelihood, however, was that the burden would fall particularly on weakened and heavily exportdependent industries such as coal. ${ }^{9}$

Even beforehand the coal industry was already struggling with unit costs that had doubled since 1913, while miners' real wages in the export districts could be as much as 50 per cent 
below pre-war levels. ${ }^{10}$ The MFGB was therefore in no mood to accept the wage reductions posted by the owners in June 1925, to come into force on 31 July. This came in the midst of attempts to revive trade-union cooperation in the wake of 1921. A conference called by a number of leading unions to consider the idea of an industrial alliance on 17 July 1925 supported industrial action in sympathy with unions felt to be under attack. The hastilyconvened court of inquiry the government set up meanwhile reported on 28 July in favour of a national minimum wage, while also pointing out the coal industry’s parlous financial state. Baldwin nevertheless that day told an MFGB delegation complaining of the effect of the Gold Standard that he would not give a subsidy. Instead, he asked Churchill to consider the mining royalties paid to landowners. Two days later, on 30 July, the Chancellor recommended gradual purchase of the royalties, costing around $£ 100$ million. ${ }^{11}$ Meanwhile, a Special Industrial Conference called by the Trades Union Congress (TUC) reacted with anger when the miners reported that the Prime Minister had told them, 'All the workers of this country have got to take reductions in wages to help put industry on its feet'. Strike notices and embargoes on coal movements were consequently issued. ${ }^{12}$ Baldwin then reconsidered his earlier position and a subsidy for nine months ending on 30 April 1926, which eventually totalled about $£ 23$ million, was agreed. This staved off the crisis.

Churchill was no enthusiast for subsidies, feeling they misallocated resources and undermined effort. He also came to feel that they were merely being used by the mine-owners to rebuild their balance sheets. ${ }^{13}$ This undoubtedly stymied his efforts to balance the nation’s books: Churchill allegedly snarled at Arthur Cook, the General Secretary of the MFGB, 'You got the subsidy over my blood-stained corpse. I have to find the money for it now.' ${ }^{14}$ No provision for such expenditure had been made in that year's Budget. Churchill nevertheless told the Commons on 6 August 1925, 'I have absolutely no doubt myself that the decision ... 
was right and wise'. His justification was that public opinion was unprepared for a dispute that would cost the nation much more. He added that temporary support for miners’ wages was justified as these had not kept pace with post-war inflation. This was, he stated, because 'in their resistance, the Government decline to discern any challenge to the State'. A challenge inspired by different forces, 'armed, inspired and taught by foreign propaganda, and, it may well be, in some cases, fed with foreign money', would be, he darkly implied, a rather different matter. ${ }^{15}$ A weekly 'Report on Revolutionary Organisation in the United Kingdom', compiled by Special Branch, makes clear what he had in mind. ${ }^{16}$

In later reflections Churchill also emphasized two other reasons: that he had not then sufficient confidence in the STO; and 'in order that a Royal Commission should have time to examine the whole position, see who was in the right, and try to find some fair compromise'. ${ }^{17}$ The Royal Commission under the former Liberal Home Secretary, Herbert Samuel, published its unanimous report on 10 March 1926. This was a bestseller, selling over 100,000 copies. It covered everything from the extraction to the distribution of coal, reflecting public concern about profiteering by coal merchants. The key recommendations, however, were nationalization of royalties, reorganization short of nationalization and improvements in working conditions. It also recommended a National Wages Board to regularize torturously complex pay structures within the industry. While these measures gradually restored the industry to financial health, the Commission recommended cessation of the subsidy. Samuel's view was that: 'It was wrong in principle that, when in some industry employers and employed could not come to terms, the taxpayer should make up the difference.' The problem was that 75 per cent of British coal was being produced at a loss, exacerbated by the return to the Gold Standard: the resulting increase in sterling's value meant that although 80,000 tons more of coal were exported in the first quarter of 1926, they 
earned $£ 1.75$ million less. Noting that living costs had fallen since the current wage settlement was fixed in 1924, Samuel's commission therefore recommended closures of uneconomic pits and cuts in wages of 10 per cent. ${ }^{18}$

A week after the Commission reported, Baldwin established a Cabinet committee to consider its recommendations. Churchill was appointed to this and later occasionally chaired it in Baldwin's absence. At its first meeting the committee noted that, although it did not entirely agree with the Commission's report, it was committed to implementing it.

Churchill's initial involvement was on the royalty nationalization issue, producing a paper on 27 March 1926 on how to achieve this. Thereafter he was busy with preparations for his Budget at the end of April. Churchill was accordingly absent when Baldwin led the committee in discussions with the MFGB on 15 April and 23 April 1926. At the latter meeting, the Prime Minister and Minister of Labour, Sir Arthur Steel-Maitland, pointed out how few of the pits in the coal-exporting districts were profitable. The MGFB responded that pits should therefore close, a view Churchill had also put forward in a speech the previous November. The MFGB President Herbert Smith was prepared to countenance 200,000 being thrown out of work rather than cut wages, arguing that the resultant loss of competition would prompt a recovery in profitability. His delegation also argued that prices, which had fallen since 1925, would increase with the end of the subsidy. ${ }^{19}$

The owners’ organization, the Mining Association of Great Britain (MAGB), told the coal committee on 21 April 1926 that miners' compensation could be about the same if they worked an eight- rather than seven-hour day. It suggested that if unit labour costs could be reduced in this way the industry might begin to recover. Evan Williams, Secretary of the 
MAGB, claimed repeal of the Seven Hour Act, after a strike of a couple of months, would produce this permanent cure. Baldwin drily responded, 'I do not think any Strike has ever been a permanent cure yet.' 20

A strike was by then looming with the TUC, as in 1925, prepared to offer sympathy action for the MFGB. On 26 April 1926, as Churchill assured the House in his Budget speech that he assumed industrial peace, Baldwin, Steel-Maitland and the Minister for Mines, G. R. Lane-Fox, embarked on a frenetic round of meetings with the TUC and MAGB. Baldwin told the latter that he understood why owners in the export districts had published wage reductions ${ }^{21}$ to be implemented once the subsidy ran out. These, however, cost public support. Baldwin therefore urged them to sort out the national minimum wage first before pursuing increases in hours, not least to give the TUC something to offer the MFGB. He warned the MAGB, 'If you have a General Strike with public opinion on your side I think the struggle will be probably short and sharp. If you have public opinion against you it might be long, and it would be difficult. ${ }^{22}$ On the grounds that its varying districts with very different profit-levels would not accept such arrangements the MAGB was unwilling to budge.

The owners remained as unmovable on costs as the miners were on wages. For the latter, reorganization, as stressed in the Samuel Report, had to be agreed before cuts. For the former, cuts had to happen to shore up the industry first. Furthermore, the wage issue was complicated by the web of profit-sharing and additional payments in cash and kind (including free coal and housing) made to various classes of miners. ${ }^{23}$ Baldwin complained at a meeting with the TUC, 'When we get through this trouble, however we get through it, it would be a mercy if we could get a simplification of their wage system. I do not believe anyone understands it.' It was almost impenetrable to anyone outside the industry. Baldwin's diatribe 
that 'If you ask either side what a man is getting they always give you different answers and neither believes what the other says’ prompted a sympathetic response from steelworkers’ leader and TUC Chairman Arthur Pugh that 'We are all in the same boat.' 24

This complexity made it difficult to counter Williams' claims that 75 per cent of pits would lose money and 60 per cent would stop production if the MFGB demands were conceded. Raising prices, he argued, would merely hit the profitability and export-potential of heavy coal-using industries like steel. What the MAGB wanted was a return to something like the 1921 minimum wage with an eight-hour day. 'That combination would be a remarkably good settlement if it could be got by agreement', Baldwin responded, adding, 'I do not see much chance of it in any circumstances. ${ }^{25}$ He did, however, make clear on 29 April to the TUC and MFGB that Churchill was prepared to concede a further subsidy of around $£ 3$ million to buy time for a settlement.

The following day, the MAGB was prevailed upon to make an offer around the 1921 minimum (effectively a 13.33 per cent reduction in the existing minimum) and an eight-hour day until the end of 1929. Late that afternoon the TUC responded that, until reorganization was agreed, the MFGB would not accept wage reductions. That evening Baldwin offered an advisory committee representing both sides to draw up reorganization proposals. Smith then reaffirmed that he would have to see to what that reorganization amounted before considering wage reductions. This, Lane-Fox noted, would require an extension of the subsidy for several years. The government considered this tantamount to rejection of the Samuel Report, and the meeting ended with Baldwin noting no clear chance of progress. That evening the King signed a proclamation of a state of emergency. 
The following morning the emergency TUC conference, convened two days earlier, voted with only one dissenting union to give powers and financial support to the organization of sympathy action in support of the miners. Ernest Bevin of the Transport \& General Workers' Union described the proclamation as a declaration of war. ${ }^{26}$ In these circumstances, at $6 \mathrm{pm}$ on Saturday 1 May, the TUC issued strike notices to support the miners, with rolling waves of workers to be called out, commencing from one minute to midnight on Monday 3 May. Baldwin was unaware of this when meeting a TUC delegation on the evening of 1 May. The railwaymen's leader J. H. Thomas then explained that the TUC lacked authority to settle on behalf of the MFGB, nevertheless suggesting that a short continuation of the subsidy might buy a fortnight to reach agreement. As Baldwin pointed out, that would involve the MFGB accepting the Samuel Report.

What happened next, and Churchill's part in it, was to be a matter of some controversy. Churchill came from Chartwell for a Cabinet meeting on the situation at noon on Sunday 2 May. The afternoon passed as the TUC tried to get hold of MFGB leaders who had returned to their districts. Meanwhile, the Cabinet learnt of the strike notices. Churchill was by no means the only minister alarmed at negotiating under such a threat. As the proclamation was issued that evening, ministers met in Churchill's rooms at No. 11 Downing Street to prepare a statement, partly drafted by Churchill, for those colleagues meeting with the TUC delegation. This expressed the view that, under the threat of a General Strike, the miners must indicate willingness to accept the Report or negotiations should end. Baldwin, Steel-Maitland and Lord Birkenhead met the TUC at 9pm, but did not give this ultimatum. Instead, they retired to meet the Cabinet at 11pm, Birkenhead reading out Thomas' statement undertaking to get the MFGB to negotiate on the Report if the subsidy continued for a fortnight. This prompted a furious argument between Churchill and his old friend Birkenhead. Dominions Secretary 
Leo Amery's diary states that of the Cabinet he alone supported Baldwin and Birkenhead in thinking this a basis for continuing negotiations. Steel-Maitland, indeed, told Parliament two days later that there was no sign that the MFGB accepted the Report, and therefore no sensible grounds for continuing the subsidy. The Home Secretary, William Joynson-Hicks, then took a telephone call informing that the printers had refused to print the Daily Mail's leading article for the following morning. J. C. C. Davidson, the Deputy Chief Civil Commissioner, noted that 'Churchill, Neville Chamberlain, Balfour, Bridgeman and Hogg successively made it clear that it must be the result of the General Strike instructions ... and the Cabinet came to the conclusion that they could no longer negotiate under the threat of a General Strike'.27

Bevin later stated in the run-up to the 1929 election that 'We were in a room in Downing Street ... when Mr Churchill saw red, walked in and upset the Cabinet, and we had that ultimatum.' 28 The New Statesman even alleged that Churchill remarked that “"a little bloodletting” would be all to the good' while leading six other ministers in resignation threats. Contemporary diary accounts of ministers present support neither of these allegations, and demonstrate that Churchill's view that negotiation should not continue on such a tentative basis without withdrawal of strike notices was widely shared by his Cabinet colleagues. An incensed Churchill wrote to the Attorney-General asking if he could sue for libel. Sir Douglas Hogg replied that he probably could, but advised against. ${ }^{29}$

Churchill's later response to Bevin argued that if the TUC really thought it had a settlement offer - and as it happened the MFGB rejected the formula - it could have temporarily withdrawn the strike notices. ${ }^{30}$ The TUC instead called out 1.5 million workers in waves in the docks, railways, printing, iron and steel, metals, chemicals, building and electricity- 
generation industries.

Meanwhile, on 3 May Joynson-Hicks reluctantly allowed Churchill for the first time to attend the STC. The production and distribution of a daily bulletin during the impending strike was discussed. As Churchill told a meeting with newspaper proprietors at noon, 'something must be done to prevent alarming news from being spread about ... I do not contemplate violent partisanship, but fair, strong encouragement to the great mass of loyal people. ${ }^{31}$ The previous year the STC had considered creating an emergency news-sheet using government printing presses at Harrow. Davidson, however, considered these inadequate and arranged to use those of the Morning Post instead. Even then the fledgling venture remained under threat when the compositors at the Morning Post joined the printers on strike. Sydney Long, the night superintendent of the Daily Express, was recruited. By working almost non-stop for three days he was able to get the enterprise under way.

It was the Air Secretary, Sir Samuel Hoare, who named the newspaper the British Gazette. His ministry was also crucial for its distribution. It was, however, Churchill who oversaw the enterprise. The intention was not to replace existing newspapers, but to pool their resources while these were no longer able to publish. The press, nevertheless, wished to return to production as soon as possible; an aim complicated by the large demands for newsprint made by the British Gazette from its first issue on 5 May. Shortages were tackled by commandeering the stocks of other newspapers, including those of the TUC-owned Daily Herald, whose presses were used to print its own journal, the British Worker. Stocks were also seized from a resentful Geoffrey Dawson, editor of The Times, while a commandeered paper-mill in Northfleet was soon producing enough paper for 1.5 million copies. Such precipitate actions were justified in a constitutional emergency by Churchill, but they were 
also strongly criticized by some of his government colleagues. ${ }^{32}$

For Churchill the British Gazette's first task was to put the government's case. His article on the front page of the first edition on 5 May 1926 stressed that while the government remained ready to provide a temporary subsidy to help resolve the trade dispute in the coal industry, the General Strike was a wholly different matter, challenging the authority of Parliament. The second task was to provide information and support morale, hence the emphasis on sufficiency of food supplies in Churchill's article on the front page of 6 May. By then the British Gazette was selling over half a million copies at 1d each. Davidson nevertheless wrote to Baldwin complaining of Churchill's interference in the operations side of the newspaper. He also insisted that 'no official news should appear which was not true, and that propaganda as such should be no part of the activities'. ${ }^{33}$ Falsely reporting that, for instance, the trains were running would undermine both the effectiveness of the British Gazette and morale. Churchill had to defend the newspaper against accusations of inaccurate reporting in the STC on 11 May 1926.

Davidson clearly felt that the STC steered Churchill's energies towards the British Gazette deliberately to keep him from wider involvement in the General Strike. In this it was not completely successful, Lane-Fox complaining that Churchill was 'belligerent and troublesome' ${ }^{34}$ Bellicose articles were toned down, but in the STC Churchill advocated a display of military force on food convoys from the London docks to overawe communist agitators. On 12 May the Tilbury convoy was attacked in retaliation to provocations from police specials, but Churchill's suggestions on convoys were rebuffed by the Cabinet, as were his and Birkenhead's demands to take over the BBC. He was more successful in persuading colleagues to agree using the Territorial Army to supplement the already stretched police. ${ }^{35}$ 
Churchill also led the rejection of the appeal by the Archbishop of Canterbury for a further subsidy for the mines and the resumption of negotiations, warning in the British Gazette on 11 May that acceptance would prove:

that the General Strike weapon had succeeded in extorting money from the Government and Parliament which both had determined to refuse ... This would be accepted as proof positive by every revolutionary element in the country that they have only to ... use the weapon of the General Strike ... to obtain control of the whole machinery of government. ${ }^{36}$

By then, the British Gazette was selling over 2 million copies. Meanwhile, normal press activities were resuming. Davidson reported to the STC that 90 per cent of dailies and 60 per cent of weeklies outside London were maintaining production. The London dailies were also keen to resume. At a meeting with the Newspaper Proprietors’ Association on 12 May Churchill agreed to end publication of the British Gazette the following day. He did, however, unsuccessfully explore copyrighting the title for use in future emergencies. ${ }^{37}$

Meanwhile, the TUC found it difficult running a potentially lengthy and costly dispute on behalf of the MFGB when the latter would not let it resolve the crisis. Samuel, meeting secretly with the TUC, drafted a memorandum setting out the basis of an agreement, but it was firmly rejected by Smith. Faced as well with a court ruling that sympathy action of this kind was not a legal strike under the 1906 Trade Disputes Act, making strike pay illegal and unions liable for damages claims, the TUC decided to call the action off on 11 May. The following morning it went to tell the Cabinet, Pugh noting that the strike was not helping to resolve the coal dispute. Nonetheless, the numbers on strike actually rose the following day before falling away. ${ }^{38}$ 
The government now considered how to prevent a repetition of the General Strike. Emergency trade union legislation was considered with Churchill's support on 8 May. It was decided not to proceed during the General Strike, but subsequently Churchill was appointed to a new Cabinet committee on the subject. His particular concern was that 'efforts were made to get the Civil Service to strike'. ${ }^{39}$ The committee recommended banning civil service unions from affiliation to the TUC, alongside tightening up trade union rules, the prohibition of sympathy strike action and stopping the requirement for union members to contract-in to membership of the Labour Party. Churchill recommended sweetening this pill with state funding for candidates, but this was not supported by the committee. ${ }^{40}$ These recommendations formed the basis of the 1927 Trade Disputes and Trade Unions Act.

Meanwhile, Baldwin met with both sides in the coal dispute as soon as the General Strike was over, offering a statutory national arbitration system and the $£ 3$ million subsidy in return for movement on wages and hours. This was rejected by both sides. The way forward, Churchill suggested on 20 May, was to permit a maximum of eight hours work per day. Longer hours were seen as a way of reducing the need for wage cuts. Churchill felt such a measure would help swiftly to end the dispute and the national cost involved. However, he recognized that permitting an extension of hours must be balanced by a guaranteed minimum wage. With assistance from Churchill on 14 June, the recalcitrant owners were bullied into accepting the latter. The following day a draft government statement announced new legislation allowing a maximum eight-hour day for miners for five years, balanced by national minimum standards. The statement claimed that 'having regard to the change in the cost of living [this] would now give a real increase 30\% higher' than in $1921 .^{41}$ 
The Coal Mines Act permitting the eight-hour day was rushed through, achieving Royal Assent on 8 July. Parallel legislation on reorganization of the industry similarly passed on 4 August. Neither, however, brought the end of the dispute nearer. It dragged on through the summer, the government making provision for coal imports to meet shortfalls. Meanwhile, miners, particularly in the inland coalfields of Nottingham and Derbyshire, were drifting back to work.

The MFGB then resumed negotiations. A national agreement remained its key objective. It feared district agreements were used to divide and rule, and would result in low wage settlements in the poorer, export districts. The owners, however, who felt national settlements gave the miners power to 'threaten and hold up the whole country', ${ }^{42}$ rejected this when they met with the MFGB on 19 August. An ailing Baldwin meanwhile went on holiday, leaving Churchill in charge of negotiations. Churchill met with the MFGB on 26 August but Smith merely asked for a resumption of the subsidy. However, this option had been dropped by the coal committee in June, with the money instead allocated to resettle unemployed miners. Given that 'Iron and Steel and shipbuilding are suffering more ... it would be absolutely unfair and impossible to subsidise for any protracted period any industry ... at the expense of the other industries’ was Baldwin's argument to a churches' delegation on $19 \mathrm{July.}^{43}$

Churchill’s conciliatory speech in the Commons on 31 August prompted Ramsay MacDonald, the leader of the Labour Party, to try to reopen negotiations, securing an MFGB note that it was willing to negotiate on labour costs. To try to meet MFGB objections to district agreements, Churchill suggested placing these within a national framework. This the MAGB rejected. Attempting to break the deadlock, Churchill wrote to Williams on 8 September. Appealing on behalf of the 1.7 million families affected by the dispute, Churchill 
offered a formulation of 'district settlements concluded in conformity with the agreed general principles' under the national body suggested in the Samuel Report. ${ }^{44}$

Steel-Maitland feared this well-intentioned intervention only stiffened the resistance of an MAGB already scenting victory. As Philip Cunliffe-Lister, the President of the Board of Trade, pointed out, the inefficient owners wanted the cheapest settlement possible. Churchill suggested to the coal committee on 14 September that, faced with their refusal, the government should coerce the owners. Cunliffe-Lister's memorandum to that same meeting, however, warned that they could not coerce the owners and then find the MFGB still rejected a settlement. He suggested instead district agreements policed by an independent tribunal, suspending the eight-hours legislation if the owners flouted this. This formed the basis of a time-limited offer drafted by Churchill for the newly-returned Prime Minister on 17 September.

The MFGB felt this went back on Churchill's position of 8 September. Meeting with Baldwin on 21 September, however, it now indicated readiness to negotiate on the basis of the 1921 wage levels, but still wanted a national settlement. Churchill was anxious to seize this opportunity, but most of the Cabinet felt the two sides remained far apart. Majority opinion among Conservative MPs was, Lane-Fox noted, 'that Winston had started a new and unnecessary stage of interference', with the proposed tribunal widely felt likely to disrupt the resumption of trade. The offer, in any case, as Churchill reminded the Commons in a vigorous speech on 27 September, would only remain open for a few more days. It was rejected by the MFGB on 7 October. ${ }^{45}$

At the start of November Churchill suggested withdrawal of poor relief from miners' families 
to hasten the end of the dispute, an idea swiftly dropped. ${ }^{46}$ By then a quarter of the men had returned to work. Pugh, meanwhile, brought a TUC delegation to see Baldwin and Churchill on 26 October to try to revive talks. He averred that the MFGB would now accept district agreements, but that was immediately repudiated by Smith when Baldwin and Churchill met with the union on 5 November. These talks dragged on, Churchill reassuring Cook that the eight-hour day was a maximum, not a requirement. When, however, he was told that the MFGB remained committed to seven hours he responded, 'If that is the position it is a waste of time to go on. ${ }^{47} \mathrm{~A}$ major problem with both owners and miners was that such delegations had to go back to their districts to secure approval for any settlement negotiated. It was only on 12 November that a delegate conference of the MFGB accepted the terms. That same day the MAGB rejected them. Meanwhile, on 11 November, the coal committee discussed a draft bill to ensure certain minimum standards and an arbitration authority. Before this could be taken much further, however, the drift back to work became a flood, with the MFGB settling by the end of the month on those local agreements they had so long resisted.

This brought to an end a dispute costing 162 million working days. It and the General Strike were of course linked. Yet, as Churchill put it on 4 May:

There are two disputes on: there is the General Strike which is a challenge to the Government and with which we cannot compromise ... There is also a trade dispute in the coal industry: on that we are prepared to take the utmost pains to reach a settlement in the most conciliatory spirit. ${ }^{48}$

This explains the very different attitude he took to each. To the General Strike he was implacably opposed. It has been suggested that he nevertheless helped to cause it by his return to the Gold Standard. Ironically, Churchill had argued that the price stability return would bring should end the series of industrial convulsions endured since the Great War. ${ }^{49}$ In 
the short-term he was spectacularly incorrect. Yet the role of gold in causing the events of 1926 is easily exaggerated. With the impact on real wages proving much less than Keynes feared, gold was more a factor in 1925 than in 1926.

Churchill nevertheless determined the timing and to some extent the nature of the dispute that broke out then through the expiration of the subsidy conceded earlier. This bought time but not a solution to the coal industry's problems: as he later complained, 'Both sides lapped up the subsidy like cats drinking cream and thought no more of the future. ${ }^{50}$ He was not directly involved in wider preparations for industrial conflict, though his public persona gave credence to the slurs about his part in 'fighting a tremendous revolution and holding it down, fist and jaw' subsequently put about by political opponents. ${ }^{51}$ Nor was he the only member of the Cabinet to feel that they were facing down a 'revolutionary strike’ ${ }^{52}$ Churchill's high profile as editor of the British Gazette nonetheless suggested that he had a much more prominent role in the management of the conflict than was the case. No wonder, in what they saw as part of the same problem, his Labour counterparts found his later efforts to settle the coal dispute surprising.

To Churchill, however, it was a wholly different matter. He warned that merely labelling Cook as a Bolshevik and siding accordingly with the owners risked giving credence to the language of class conflict. Instead, he wrote to his mine-owning cousin, the Marquess of Londonderry, 'The duty of the Government is to occupy an impartial position in the interests of the State and of the whole community. ${ }^{53}$ Bringing two 'thoroughly unreasonable' parties to compromise, however, was fraught with difficulties and ran the risk of stiffening the resistance of one or the other. Lane-Fox had a point when complaining that in attempting this duty Churchill 'tries to find short-cuts to settlement through impassable country'. ${ }^{54}$ 
Footnotes

${ }^{1}$ House of Commons Debates, 5th ser., vol. 199, cc. 212-24.

${ }^{2}$ Report of the Twenty-sixth Annual Conference of the Labour Party (London: Labour Party, 1926), p.94.

${ }^{3}$ Even with post-war reductions, by 1925 there were still around 2,500 pits of greatly varying efficiency.

${ }^{4}$ Confidential notes, c.1911, CHAR 12/6/40-49.

${ }^{5}$ Draft article for the News of the World, c.October 1937, CHAR 8/567/1-19.

${ }^{6}$ Cited in Paul Addison, Churchill on the Home Front 1900-1955 (London: Pimlico, 1993), pp. 205, 213.

7 'Supply and Transport Committee Report’, 14 July 1925, The National Archives, Kew, CAB 27/261, ST(24)5.

${ }^{8}$ Peter Catterall, 'Churchill as Chancellor of the Exchequer (1924-9) and the Return to the Gold Standard', www.churchillarchive.com.

${ }^{9}$ J. M. Keynes, 'The Economic Consequences of Mr Churchill', Essays in Persuasion (London: Macmillan, 1931), pp. 244-70, http://www.gutenberg.ca/ebooks/keynesessaysinpersuasion/keynes-essaysinpersuasion-00-h.html\#Footnote_24_24.

${ }^{10}$ British Weekly, 28 February 1924, 6 March 1924.

${ }^{11}$ Churchill was, however, to change his mind about taking on this cost in the straitened circumstances of 1926, and nationalization of mining royalties was not enacted until 1938. ${ }^{12}$ Alan Bullock, The Life and Times of Ernest Bevin: Volume 1, Trade Union Leader 18811940 (London: Heinemann, 1960), pp. 277-8.

${ }^{13}$ Winston Churchill to Sir George Barstow, 20 March 1926, CHAR 18/30A-B/172.

${ }^{14}$ Walter Citrine, Men and Work (London: Hutchinson, 1964), p. 142.

${ }^{15}$ House of Commons Debates, 5th ser., vol. 187, cc. 1677-91. In 1926 Russian money was 
offered to and rejected by the TUC. The MFGB, however, was to receive $£ 1,233,788$ in donations from Russian trade unionists. See Daniel F. Calhoun, The United Front: The TUC and the Russians 1923-1928 (Cambridge; Cambridge University Press, 2008), pp. 239-41, $250-52$.

${ }^{16}$ Metropolitan Police Special Branch, 'Report on Revolutionary Organisations in the United Kingdom’, 15 April-12 August 1926, CHAR 22/148.

${ }^{17}$ Draft article for the News of the World, c.October 1937, CHAR 8/567/11.

${ }^{18}$ Viscount (Herbert) Samuel, Memoirs (London: Cresset Press, 1945), pp. 184-6; Minutes of meeting with TUC, 28 April 1926, 6.40 pm, The National Archives, CAB 27/317, RCC(26)24, p. 14; G. R. Lane-Fox, Report of the Coal Commission, 22 June 1926, The National Archives, CP251(26), CHAR 22/96/117-122.

${ }^{19}$ Thomas Jones, Whitehall Diary: Volume II, 1926-1930, edited by Keith Middlemas (London: Oxford University Press, 1969), p. 18.

${ }^{20}$ The National Archives, CAB 27/317, RCC(26)11, RCC(26)14.

${ }^{21}$ Inland coalfields such as Nottinghamshire, Derbyshire and Warwickshire were profitable and no notices were issued: 'Misleading Statements as the Breakdown', undated memorandum, CHAR 22/141/51-53.

2226 April 1926, The National Archives, CAB 27/317, RCC(26)17, pp. 3-4.

${ }^{23}$ See CHAR 22/141/60 for a simplified explanation.

${ }^{24} 28$ April 1926, 6.40 pm, The National Archives, CAB 27/317, RCC(26)24, p. 1.

2527 April 1926, 6.55 pm The National Archives, CAB 27/317, RCC(26)22; 28 April 1926, 3.00 pm, The National Archives, CAB 27/317, RCC(26)23, especially p.58.

${ }^{26}$ Bullock, The Life and Times of Ernest Bevin, pp. 305-6.

${ }^{27}$ John Barnes and David Nicholson (eds), The Leo Amery Diaries: Volume 1 1896-1929 (London: Hutchinson, 1980), pp. 450-52; Stuart Ball (ed.), Conservative Politics in National 
and Imperial Crisis: Letters from Britain to the Viceroy of India 1926-31 (Farnham: Ashgate, 2014), pp. 29-30; cited in Martin Gilbert, Winston S. Churchill: Volume V, 1922-1939 (London: Heinemann, 1976), p.150.

${ }^{28}$ Message from Associated Press, April 1929, CHAR 2/164/11-12.

29 ‘Should we hang Mr Churchill or not?’, New Statesman, 22 May 1926, pp. 132-3, CHAR 2/147/92-93; Winston Churchill to Sir Douglas Hogg, 26 May 1926, CHAR 2/147/90-91; Sir Douglas Hogg to Winston Churchill, 28 May 1926, CHAR 2/147/101.

${ }^{30}$ Bullock, The Life and Times of Ernest Bevin, pp. 311-14; CHAR 2/164/26-27.

${ }^{31}$ Notes of meeting, 3 May 1926, CHAR 22/142/35.

${ }^{32}$ Winston Churchill to Geoffrey Dawson, 8 May 1926, CHAR 22/143/10-12; Ball, Conservative Politics, p. 32; Barnes and Nicholson, The Leo Amery Diaries, pp 453-4; 'Copy of Report to the Cabinet re the "British Gazette”, 25 May 1926, CHAR 22/142/119-132.

${ }^{33}$ Ball, Conservative Politics, p. 51.

${ }^{34}$ Ball, Conservative Politics, p. 39.

${ }^{35}$ STC 24th conclusions, 12 May 1926, The National Archives, CAB 27/260; Gilbert, Winston S. Churchill: Volume V, pp. 163-4.

${ }^{36}$ British Gazette, 11 May 1926, CHAR 2/148/1. This file contains a complete run of issues.

${ }^{37}$ W. R. Codling to E. H. Marsh, 1 June 1926, CHAR 22/143/101.

${ }^{38}$ Ball, Conservative Politics, p.36; Samuel, Memoirs, pp. 187-91; Citrine, Men and Work, pp. 199-213; Bullock, The Life and Times of Ernest Bevin, p. 317.

${ }^{39}$ Winston Churchill to Sir Warren Fisher, 22 February 1927, CHAR 18/68/13-14; The National Archives, CAB 27/325.

${ }^{40}$ Addison, Churchill on the Home Front, pp. 269-70.

41 ‘The Coal Dispute’, 15 June 1926, CP 239(26), CHAR 22/96/53-54.

${ }^{42}$ STC 30th conclusions, 30 August 1926, The National Archives, CAB 27/260, citing 
Williams’ letter to Lane-Fox, 29 August 1926.

${ }^{43}$ Philip Williamson and Edward Baldwin (eds), Baldwin Papers: A Conservative Statesman 1908-1947 (Cambridge: Cambridge University Press, 2009), p. 185.

${ }^{44}$ Arthur Cook, letter to Winston Churchill, 3 September 1926, Winston Churchill, letter to Evan Williams, 8 September 1926, The National Archives, CAB 27/319.

${ }^{45}$ Ball, Conservative Politics, pp. 89-90; Gilbert, Winston S. Churchill: Volume V, pp. 21314.

${ }^{46}$ Addison, Churchill on the Home Front, p. 267.

478 November 1926, The National Archives, CAB 27/319, RCC(26)87.

${ }^{48}$ Jones, Whitehall Diary, p.36.

${ }^{49}$ House of Commons Debates, 5th ser., vol. 183, cc. 671-2, 4 May 1925.

${ }^{50}$ Speaking in his constituency on 1 November 1926, Gilbert, Winston S. Churchill: Volume $V$, p. 216.

${ }^{51}$ H. G. Wells, Meanwhile (London: Doran, 1927), p. 106.

${ }^{52}$ Philip Williamson (ed.), The Modernisation of Conservative Politics: The Diaries and Letters of William Bridgeman 1904-1935 (London: Historians’ Press, 1988), p.198. See also William Joynson-Hicks, ‘Russian Money’, CP 236(26), 11 June 1926, CHAR 22/96/4-15.

${ }^{53}$ Winston Churchill to Marquess of Londonderry, 3 November 1926, CHAR 18/28/106-108.

${ }^{54}$ Speaking in his constituency on 1 November 1926, Gilbert, Winston S. Churchill: Volume V, p. 216; Ball, Conservative Politics, p. 104.

\section{About the Author}

Dr Peter Catterall MA (Cantab) PhD (Lond) FRHistS is Reader in History at the University of Westminster. He has published extensively on nineteenth- and twentieth-century British political, constitutional, social and cultural history, and is probably best known as the editor 
of the diaries of former Prime Minister Harold Macmillan. His latest publications are Labour and the Politics of Alcohol: The Decline of a Cause (2014) and 'Prime Minister and President: Harold Macmillan’s Accounts of the Cuban Missile Crisis’ in Len Scott and R. Gerald Hughes (eds), The Cuban Missile Crisis: A Critical Reappraisal (2015).

\section{Documents from the Archive}

British Gazette, 5-13 May 1926, CHAR 2/148 and CHAR 22/145

General Strike newspaper cuttings, 1926, CHAR 2/149

General Strike correspondence, 1929, CHAR 2/164

‘Should we hang Mr Churchill or not?’, New Statesman, 22 May 1926, CHAR 2/147/92-93

Winston Churchill to Sir James Hawkey, 16 November 1926, CHAR 2/147/167-173

Winston Churchill, draft article on the General Strike, 1937, CHAR 8/567/1-19

Winston Churchill, speech notes including for statements on the coal dispute of 2 July, 1 August and 27 September 1926, and for his speech winding up the censure debate called by the Labour opposition, 8 December 1926, CHAR 9/76

Coal dispute correspondence, September 1926, CHAR 18/28

Winston Churchill, letter to Sir Warren Fisher, 22 February 1927, CHAR 18/68/13-14

Winston Churchill, correspondence with the MAGB and MFGB, and Cabinet memoranda after the General Strike, 1926, CHAR 22/95

Cabinet memoranda after the General Strike, 1926, CHAR 22/96

Cabinet Supply and Transport Committee papers, 29 April 1926 to 27 July 1927, CHAR $22 / 128$

General Strike and British Gazette cuttings and correspondence, CHAR 22/141, CHAR 22/142, CHAR 22/143

British Gazette draft material, CHAR 22/144 
Metropolitan Police Special Branch, 'Report on Revolutionary Organisations in the United Kingdom’, 15 April-12 August 1926, CHAR 22/148

\section{Further Reading}

Paul Addison, Churchill on the Home Front 1900-1955 (London: Jonathan Cape, 1992)

Stuart Ball (ed.), Conservative Politics in National and Imperial Crisis: Letters from Britain to the Viceroy of India 1926-31 (Farnham: Ashgate, 2014)

John Barnes and David Nicholson (eds), The Leo Amery Diaries: Volume 1 1896-1929

(London: Hutchinson, 1980)

S. N. Broadberry, The British Economy Between the Wars: A Macroeconomic Survey

(Oxford: Blackwell, 1986)

Alan Bullock, The Life and Times of Ernest Bevin: Volume 1, Trade Union Leader 18811940 (London: Heinemann, 1960)

Walter Citrine, Men and Work (London: Hutchinson, 1964)

Martin Gilbert, Winston S. Churchill: Volume V, 1922-1939 (London: Heinemann, 1976)

Martin Gilbert, Winston S. Churchill: Companion Volume V: Part 1: The Exchequer Years, 1922-1929 (London: Heinemann, 1979)

Martin Gilbert, Winston S. Churchill: Companion Volume V: Part 2: The Wilderness Years, 1929-1935 (London: Heinemann, 1981)

Robert Rhodes James (ed.), Memoirs of a Conservative: J. C. C. Davidson's Memoirs and Papers (London: Weidenfeld and Nicolson, 1969)

Thomas Jones, Whitehall Diary: Volume 2 1926-1930, edited by Keith Middlemas (Oxford: Oxford University Press, 1969)

Margaret Morris (ed.), The General Strike (Harmondsworth: Penguin, 1976)

Anne Perkins, A Very British Strike: 3 May-12 May 1926 (London: Pan Macmillan, 2006) 
Herbert Samuel, Memoirs (London: Cresset Press, 1945)

Philip Williamson (ed.), The Modernisation of Conservative Politics: The Diaries and Letters of William Bridgeman 1904-1935 (London: Historians’ Press, 1988)

Philip Williamson, Stanley Baldwin: Conservative Leadership and National Values

(Cambridge: Cambridge University Press, 1999)

Philip Williamson, National Crisis and National Government: British Politics, the Economy and Empire, 1926-1932 (Cambridge: Cambridge University Press, 2003)

Philip Williamson and Edward Baldwin (eds), Baldwin Papers: A Conservative Statesman 1908-1947 (Cambridge: Cambridge University Press, 2009) 